\title{
ESTIMATING THE VOLATILITY OF ELECTRICITY PRICES: THE CASE OF THE ENGLAND AND WALES WHOLESALE ELECTRICITY MARKET
}

\section{Sherzod N. Tashpulatov}
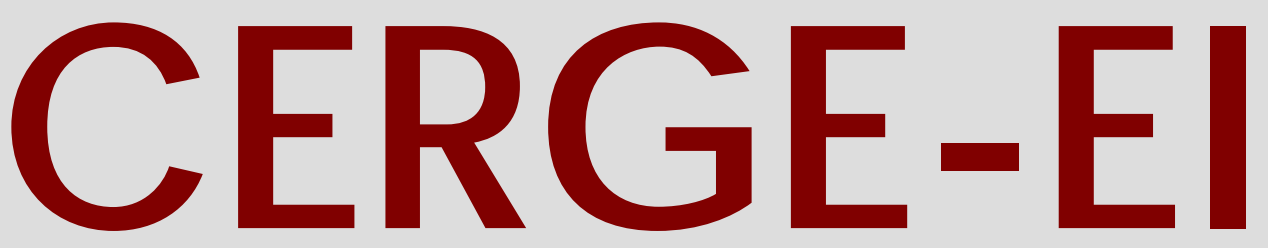

Charles University Centerfor Economic Research and Graduate Education Academy of Sciences of the Czech Republic Ec onomic s Institute 


\title{
Working Paper Series (ISSN 1211-3298)
}

\section{Estimating the Volatility of Electricity Prices: The Case of the England and Wales Wholesale Electricity Market}

\author{
Sherzod N. Tashpulatov
}

CERGE-EI

Prague, May 2011
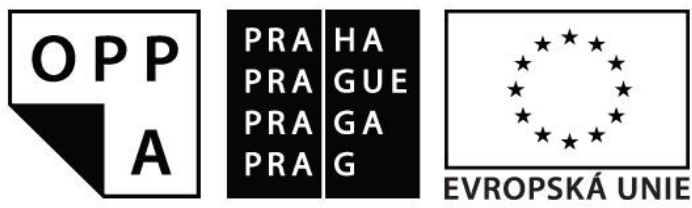

EVROPSKÝ SOCIÁLNÍ FOND

PRAHA \& EU: INVESTUJEME DO VAŠÍ BUDOUCNOSTI 
ISBN 978-80-7343-240-9 (Univerzita Karlova. Centrum pro ekonomický výzkum a doktorské studium)

ISBN 978-80-7344-231-6 (Národohospodářský ústav AV ČR, v.v.i.) 


\title{
Estimating the Volatility of Electricity Prices: The Case of the England and Wales Wholesale Electricity Market*
}

\author{
Sherzod N. Tashpulatov \\ CERGE-EI ${ }^{\dagger}$
}

\begin{abstract}
Price fluctuations that partially comove with demand are a specific feature inherent to liberalized electricity markets. The regulatory authority in Great Britain, however, believed that sometimes electricity prices were significantly higher than what was expected and, therefore, introduced price-cap regulation and divestment series. In this study, I analyze how the introduced institutional changes and regulatory reforms affected the dynamics of daily electricity prices in the England and Wales wholesale electricity market during 1990-2001.

This research finds that the introduction of price-cap regulation did achieve the goal of lowering the price level at the cost of higher price volatility. Later, the first series of divestments is found to be successful at lowering price volatility, which however happens at the cost of a higher price level. Finally, this study also documents that the second series of divestments was more successful at lowering both the price level and volatility.
\end{abstract}

\begin{abstract}
Abstrakt
Cenové fluktuace, jež se částečně spolupohybují s poptávkou, jsou specifickým rysem liberalizovaných trhů s elektřinou. Regulační orgán ve Velké Británii se však domníval, že ceny elektřiny byly někdy výrazně vyšší, než se očekávalo, a z toho důvodu tedy zavedl regulaci cenovými omezeními a sérii divestitur. V tomto výzkumu analyzuji, jaký dopad zavedení institucionálních změn a regulačních reforem mělo na dynamiku denních cen elektřiny na anglickém a velšském velkoobchodním trhu v letech 1990-2001.

Tento výzkum dospívá k závěru, že zavedení regulace pomocí cenových omezení dosáhlo zamýšleného snížení cenové úrovně za cenu vyšší cenové volatility. Dále je zjištěno, že první vlna divestitur byla úspěšná při snižování cenové volatility, což se ale stalo za cenu vyšší cenové hladiny. Výzkum také nakonec přináší důkazy, že druhá vlna divestitur byla úspěšnější při snižování jak cenové úrovně, tak volatility.

Keywords: electricity prices, seasonality, Fourier transform, conditional volatility, regulation

JEL Classification: C22, C51, L50, L94

*I would like to express my gratitude to Lubomír Lízal for supervising this research. I am thankful to Jan Kmenta, Evžen Kočenda, and Petr Zemčík for detailed comments on earlier drafts. I am also thankful to Richard Stock for help and advice on English language. All remaining errors are mine.

${ }^{\dagger}$ A joint workplace of the Center for Economic Research and Graduate Education, Charles University, and the Economics Institute of the Academy of Sciences of the Czech Republic

Address: CERGE-EI, P.O. Box 882, Politickych veznu 7, Prague 111 21, Czech Republic

E-mail: stashpul@cerge-ei.cz
\end{abstract}




\section{Introduction}

Fluctuations in electricity prices are usually explained by electricity being nonstorable and the critical need to continuously meet market demand. Prior to liberalization, price fluctuations were generally minimal and controlled. However, after liberalization, during the history of the England and Wales wholesale electricity market, price fluctuations, caused by frequent spikes, were sometimes excessively large. Large fluctuations in electricity prices generally introduce uncertainties about revenues for producers and costs for retail suppliers, which could result in higher prices paid by consumers.

The regulatory authority, the Office of Electricity Regulation (OFFER), believed that excessively high prices and fluctuations were possibly the result of the exercise of market power by incumbent electricity producers (National Power and PowerGen). Hence, in order to decrease the influence of the incumbent producers, the regulatory authority introduced price-cap regulation and divestments.

This empirical study quantitatively evaluates the impact of institutional changes and regulatory reforms on price and volatility dynamics. For this purpose I consider an $A R-A R C H$ model, which is extended to include periodic sine and cosine functions to accommodate weekly seasonality. The application of periodic sine and cosine functions, rather than daily dummy variables, is found to lead to a more parsimonious model. Finally, in order to analyze the impact of institutional changes and regulatory reforms on price and volatility dynamics, I also include regime dummy variables, which are created based on the timeline described in Figure 3.1.

The adopted methodology allows evaluating the impact of regulation on price and volatility dynamics during the liberalization process. This research documents new evidence of the impact of price-cap regulation and divestment series on price level and volatility. In particular, I find that the price-cap regulation was successful at lowering the price level, which however happened at the cost of higher price volatility. Later, after the first series of divestments was introduced, the trade-off reversed. I explain this as the evidence of possible tacit collusion, which is also discussed in Sweeting (2007). The research finally documents that the second series of divestments was more successful at ensuring lower price level and volatility.

Paul Joskow characterized the privatization, restructuring, market design, and regulatory reforms pursued in the liberalization process of the electricity industry in England and Wales as the international gold standard for energy market liberalization (Joskow, 2009). In this respect, the findings and conclusions of this research could be of interest 
to countries that formed or are about to form the operation of their modern electricity markets based on the original model of the England and Wales wholesale electricity market.

\section{Literature Review}

After the liberalization of energy industries started in different countries, it became important to model and forecast price development. This is of special interest to producers and retail suppliers because price fluctuations now introduce uncertainties about revenues and costs. A government is also usually interested in understanding price developments resulting, for example, from auctions, because they eventually define the costs that consumers will have to face. High costs for energy, besides decreasing the economic welfare of consumers, may also at times undermine the political stability of a country.

Green and Newbery (1992) and Von der Fehr and Harbord (1993) are the seminal studies in modeling electricity auctions. Both of these studies apply their models for the case of the England and Wales wholesale electricity market. Green and Newbery (1992) use the framework of supply function equilibrium (SFE), where it is assumed that electricity producers submit a continuous supply function. This is usually applicable when producers' production units are small enough or when each producer has a sufficiently large number of production units as was the case, for example, with National Power and PowerGen. The authors show that a producer with a larger production capacity has more incentive to exercise market power by submitting price bids in excess of marginal costs.

Von der Fehr and Harbord (1993) consider $N$ electricity producers serving the wholesale electricity market operated as a uniform price auction. The authors demonstrate that no pure-strategy bidding equilibrium exists when electricity demand falls within a certain range. Their result is explained by an electricity producer's conflicting incentives to bid high in order to set a high price and to bid low in order to ensure that its production unit is scheduled to produce electricity.

Wolfram (1998) and Crawford et al. (2007) empirically examine the bidding behavior of electricity producers in the wholesale electricity market in England and Wales. Wolfram (1998) finds that electricity producers submit price bids reflecting higher markups for production units that are likely to be scheduled to produce electricity if that producer has a large infra-marginal production capacity. The author indicates that the incentive to submit a price bid reflecting a higher markup for a certain production unit is moderated 
by the presence of the threat that the production unit might not be scheduled to produce electricity. Wolfram (1998) also finds that larger producers tend to submit higher price bids than smaller producers for comparable production units (i.e., production units using the same input to produce electricity and having almost the same marginal costs).

Crawford et al. (2007) empirically establish the presence of asymmetries in the bidding behavior of marginal and infra-marginal electricity producers: during the highest-demand trading periods marginal electricity producers behave strategically by submitting price bids higher than their marginal costs, whereas infra-marginal electricity producers behave competitively by submitting price bids reflecting their marginal costs.

Sweeting (2007) analyzes the development of market power in the same electricity market. The author measures market power as the margin between observed wholesale market prices and estimates of competitive benchmark prices, where the latter is defined as the expected marginal cost of the highest-cost production unit required to meet electricity demand. Sweeting (2007) finds that electricity producers were exercising increased market power. This finding, as the author indicates, is however in contradiction with oligopoly models, which, when market concentration was falling, would have predicted a reduction in market power. Sweeting (2007) also finds that from the beginning of 1997 the incumbent electricity producers could have increased their profits by submitting lower price bids and increasing output. These findings are explained as tacit collusion.

In the following paragraphs I describe the development of modeling techniques applied for price time series from deregulated electricity supply industries in different countries. This research has been important for my development of the modeling approach to analyze the impact of institutional changes and regulatory reforms on price and volatility dynamics for the case of the England and Wales wholesale electricity market during 1990-2001.

Crespo et al. (2004) consider the $A R$ and $A R M A$ models to analyze hourly electricity prices from the Leipzig Power Exchange during June 16, 2000 - October 15, 2001. The authors' main finding is that models where each hour of the day is studied separately yield uniformly better forecasts than models for the whole time series. Guthrie and Videbeck (2007) analyze half-hourly prices during November 1, 1996 - April 30, 2005 from the New Zealand Electricity Market (NEM). The authors similarly find that half-hourly trading periods naturally fall into five groups of trading periods, which can be studied separately. For modeling purposes, the price time series is decomposed into deterministic and stochastic parts. The deterministic part is modeled using a dummy variable approach to take into account the day-of-the-week and month effects. The residuals, which are also 
called "filtered prices," represent the stochastic part and are modeled using a periodic autoregressive process. For each group Guthrie and Videbeck (2007) consider a periodic model, where a half-hourly price is regressed on the price during the previous trading period and the previous day's price during the same trading period. A detailed overview of periodic time series models is provided, for example, in Franses and Paap (2004).

Huisman et al. (2007) treat hourly electricity prices from the Amsterdam Power Exchange (APX), the European Energy Exchange (EEX; Germany), and the Paris Power Exchange (PPX) for the year 2004 as a panel in which hours represent cross-sectional units and days represent the time dimension. The authors apply the seemingly unrelated regressions (SUR) method.

The findings in Crespo et al. (2004), Guthrie and Videbeck (2007), and Huisman et al. (2007) that each trading period or a group of trading periods should be studied separately across trading days, rather than as a whole hourly (or half-hourly) time series, may be the consequence of the application of hourly, daily, and monthly dummy variables for a timevarying intercept term (or the deterministic component), which could not accommodate multiple types of seasonality as well as, for example, smooth periodic sine and cosine functions considered in this research.

Conejo et al. (2005) find evidence that dynamic modeling is preferable to seasonal differencing when dealing with time series containing multiple types of seasonality. In particular, using the PJM interconnection data for the year 2002, the authors find that the $A R M A$ dynamic regression models for different seasons, which include hourly, daily, and weekly lags, are more effective in forecasting electricity prices than the ARIMA regression models for different seasons, which include hourly, daily, and weekly differencing. This finding justifies my inclusion of lags to accommodate seasonality patterns, which is crucial because otherwise the regulation analysis for a transformed time series (like the removal of a deterministic seasonal component or seasonal differencing) may be incorrect.

However, none of the above studies model the volatility process, which is important for the risk and uncertainty measures. In contrast, Garcia et al. (2005) consider a GARCH methodology to model and forecast hourly prices in the Spanish and California electricity markets during 1999-2000. The authors find that in terms of forecasting, their GARCH model outperforms a general $A R I M A$ model when volatility and price spikes are present. Bosco et al. (2007) also consider a GARCH methodology to model the dynamics of daily average prices of the Italian wholesale electricity market created in 2004. The deterministic part of the price time series is modeled using low-frequency components and the stochastic part using a periodic $A R-G A R C H$ process. The authors find that the 
periodic modeling approach seems most appropriate to account for the different amount of memory of past prices that each weekday carries, as well as the presence of spikes and volatility clustering in electricity prices.

Koopman et al. (2007) similarly study daily average prices from the electricity markets in France, Germany, the Netherlands, and Norway. The authors find that a seasonal periodic autoregressive fractionally integrated moving average process with $A R C H$ disturbances is the appropriate process to consider for the analysis of daily log-transformed electricity spot prices. This approach is however complex and dependent on the order of seasonal fractional integration, which should not violate the stationarity and invertibility conditions. Another challenging feature is that it is difficult to provide an intuitive interpretation to non-integer differencing.

In general, a major challenge of applying a periodic $A R$ process considered, for example, in Guthrie and Videbeck (2007), Bosco et al. (2007), and Koopman et al. (2007) is the requirement to estimate a large number of parameters. In their study, Koopman et al. (2007) suggest, as possible extensions, applying smoothly time-varying parameters for modeling the dynamics of electricity prices, which may lead to a more parsimonious model. This suggestion is considered in Section 5.

\section{The England and Wales Electricity Market}

At the start of liberalization, a wholesale market for electricity trading was organized in England and Wales. This market operated through a half-hourly uniform price auction managed by the National Grid Company (NGC). The resulting half-hourly uniform auction price, which is also known as the System Marginal Price (SMP), determined a payment to producers for electricity production.

The regulatory authority, the Office of Electricity Regulation (OFFER), noticed cases of excessively high electricity prices, which were attributed to the possible noncompetitive bidding behavior of the incumbent electricity producers (National Power and PowerGen). In order to decrease the influence of the incumbent electricity producers and thereby reduce the incidence of price spikes leading to price fluctuations being significantly higher than expected, the regulatory authority introduced several reforms in the Electricity Supply Industry (ESI) in Great Britain. The time of the introduced institutional changes and regulatory reforms define different regime periods, which are summarized in Figure 3.1.

At the time of the creation of the wholesale electricity market, coal and other contracts 


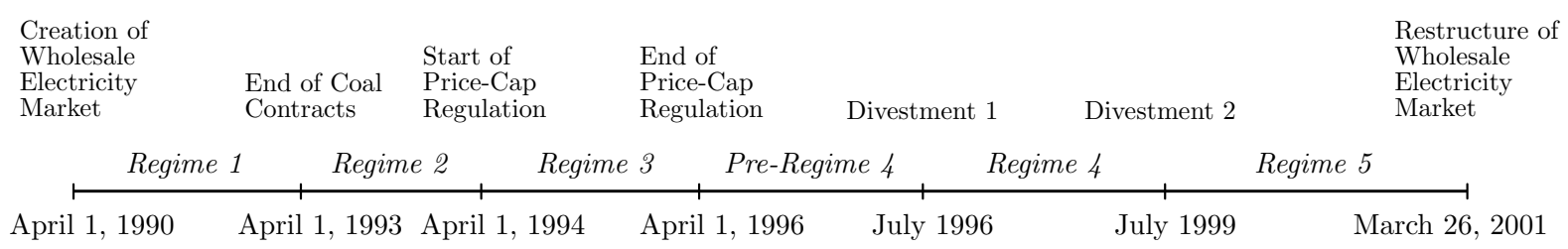

Sources: Department of Trade and Industry (1997-2002), National Grid Company (1994-2001), Newbery (1999), Robinson and Baniak (2002), Wolfram (1999); author's illustration.

Figure 3.1: Institutional Changes and Regulatory Reforms in the ESI in Great Britain during 1990-2001

were introduced by the government, which then expired in 1993. The end of coal contracts is expected to lead to higher price volatility because of increased uncertainty about market prices of coal, which is one of the major inputs in electricity production.

Later, because the regulatory authority believed that the excessively high prices were resulting from the noncompetitive bidding behavior of the incumbent electricity producers, it introduced price-cap regulation and divestments. The price-cap regulation during 1994-1996 was a temporary measure designed to control annual average prices set by the incumbent electricity producers. Later, in order to decrease market concentration and improve competition, the incumbent electricity producers were asked to divest part of their production facilities, which took place in 1996 and 1999.

When defining regime periods for an ex-post regulation analysis, I consider the exact dates when the reforms were introduced. This approach, which in particular better corresponds to the nature of the divestment series introduced by the regulatory authority, is also applied in Tashpulatov (2010). For example, the introduction of the first series of divestments for PowerGen led to the transfer of all medium coal production facilities to Eastern Group (National Grid Company, 1994-2001). In that study a separate analysis of the bidding behavior of PowerGen with respect to medium coal production facilities several days or weeks before the actual divestment took place may not be statistically reliable due to a small number of observations. For Eastern Group, it would not be possible because Eastern Group did not have coal production facilities before and therefore could not participate in the auction by submitting bids for coal production units. Hence, in order to be consistent, in this study I assume that the structural breaks are exogenously given by the dates when the reforms were introduced.

It is worth mentioning that the structural changes introduced through the divestment series differ, because the first series of divestments included the lease and the second series included the sale of production facilities (National Grid Company, 1994-2001). 
Therefore, the effect of the two divestment series, generally, need not be the same.

In March 2001, the wholesale electricity market was restructured to introduce bilateral trading arrangements.

\section{Data}

The uniform auction price, also known as the System Marginal Price (SMP), is the halfhourly wholesale price paid to producers for electricity production. Daily electricity prices are defined as daily averages of the half-hourly SMP.

Understanding the dynamics of daily prices from liberalized electricity markets is important because these prices are usually used as a reference price for market valuations and financial contracts (Huisman et al., 2007).

Figure 4.1 describes the development and distribution of daily electricity prices for the whole history of the England and Wales wholesale electricity market.
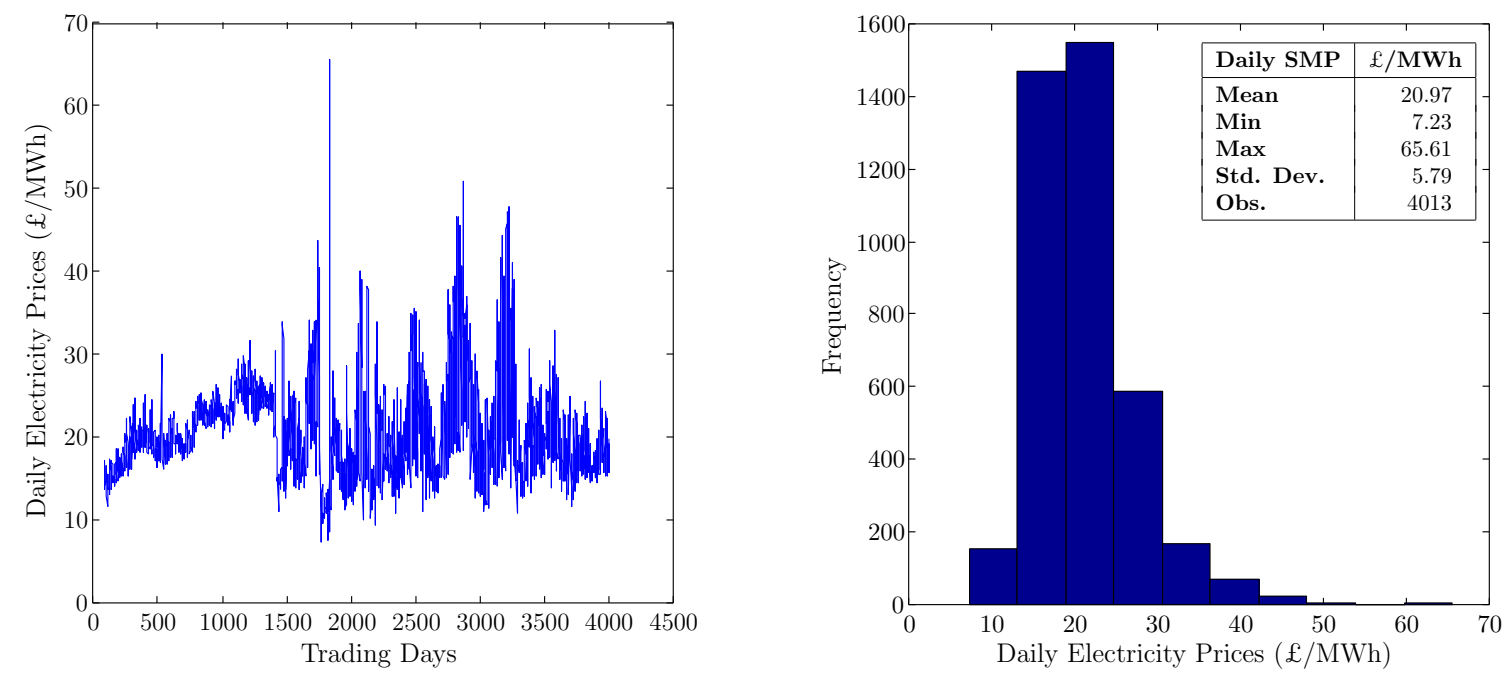

Source: Author's calculations.

Figure 4.1: Daily Electricity Prices (April 1, 1990 - March 26, 2001)

Detailed information and my acknowledgments to people and organizations I was in contact with in the process of collecting data and materials will be listed at a later stage of the dissertation research.

The observed excessively high price spikes in the mid 1990s are probably associated with some plants not being available due to maintenance and interruption of gas supplies in England and Wales and disputes in France (see Robinson and Baniak, 2002). 
In Table 4.1 I summarize the descriptive statistics of daily electricity prices during the different regime periods described in Section 3.

Table 4.1: Summary Statistics for Daily Electricity Prices (£/MWh) across Regimes

\begin{tabular}{lcccccc}
\hline & Regime 1 & Regime 2 & Regime 3 & Pre-Regime 4 & Regime 4 & Regime 5 \\
\hline Mean & 19.84 & 24.16 & 20.08 & 19.90 & 22.61 & 19.31 \\
Min & 11.49 & 10.98 & 7.23 & 12.38 & 10.71 & 11.55 \\
Max & 30.08 & 31.53 & 65.61 & 33.84 & 50.92 & 32.90 \\
Std. Dev. & 2.87 & 3.56 & 7.01 & 4.48 & 7.62 & 3.57 \\
Obs. & 1096 & 365 & 731 & 91 & 1114 & 616 \\
\hline
\end{tabular}

Source: Author's calculations.

The preliminary results based on descriptive statistics indicate that the mean and standard deviation of prices are higher after the expiration of the coal contracts. It is also interesting to note a large decrease in the mean of prices accompanied by a large increase in the standard deviation of prices during the price-cap regulation period. This could indicate a trade-off of attempting to control annual average prices at the expense of larger price fluctuations. The price fluctuations were finally stabilized after the two series of divestments, which were introduced by the regulatory authority as an attempt to decrease the overall influence of the incumbent electricity producers and thereby improve competition in the wholesale electricity market.

In order to draw statistical inferences in the analysis of the impact of institutional changes and regulatory reforms on price and volatility dynamics, I apply time series econometrics techniques. These are described in detail in Section 5.

\section{$5 \quad$ Methodology}

Before modeling the dynamics of daily electricity prices, I first conduct a stationarity test. Then I examine electricity prices using time and frequency domain analyses. The time domain analysis helps specify the $A R$ process and the frequency domain analysis helps specify the correct frequencies in periodic sine and cosine functions included as additional explanatory variables to model weekly seasonality. The volatility dynamics of electricity prices is modeled using an $A R C H$ process. Finally, in order to account for the presence of institutional changes and regulatory reforms, I enrich the set of explanatory variables to include regime dummy variables. The regime periods are determined based 
on the known time of the institutional changes and regulatory reforms that took place in the ESI in Great Britain during 1990-2001.

\subsection{Stationarity Test}

A time series is called covariance stationary if its mean and variance are constant over time and if its covariance depends only on the lag order. This is the weak form of stationarity usually employed in time series econometrics.

A stationarity test is usually conducted before any modeling step is undertaken. The main reason is that many modeling procedures and techniques are applicable to only stationary time series. In particular, correlogram and periodogram techniques, discussed in Section 5.2 and Section 5.3, respectively, also require the stationarity of a time series (see, for example, Gençay et al., 2002).

I test the stationarity of daily electricity prices using the Augmented Dickey-Fuller (ADF) test with a constant term, which allows controlling for the possible presence of a serial correlation in the residuals. As the maximum number of lags I initially chose ten, which was then changed to eight based on the statistical significance of the coefficient on the highest lag and Akaike information criterion (AIC). The unit-root null hypothesis was rejected and therefore I conclude that daily electricity prices are stationary. The results of the ADF test are summarized in Table 5.1.

Table 5.1: Augmented Dickey-Fuller Test for Daily Electricity Prices

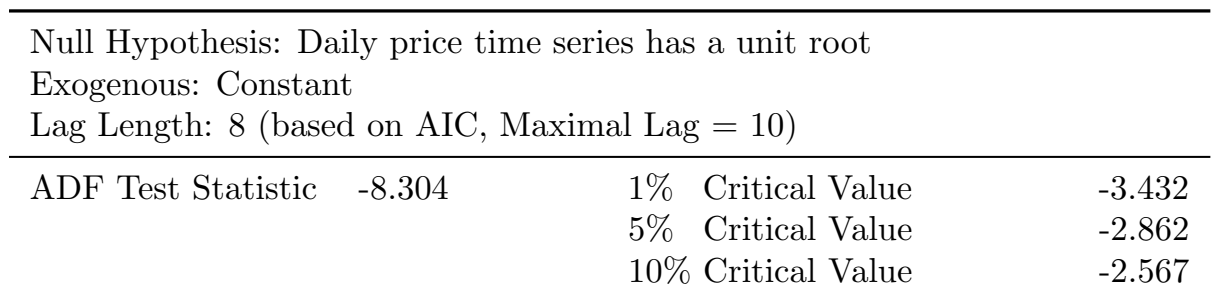

*MacKinnon critical values for the rejection of the hypothesis of a unit root.

Source: Author's calculations.

The stationarity conclusion is robust for higher order choices of the maximal lag. However, the conclusion is usually less reliable when a very high order of the maximal lag is considered. This is due to a decrease of the power of the ADF test (Kočenda and Černý, 2007). 


\subsection{Time Domain Analysis}

A time series can be analyzed on a time domain using the autocorrelation function (ACF) and partial autocorrelation function (PACF). I summarize the sample ACF and PACF for daily electricity prices in a correlogram presented in Figure 5.1 (a lag of order 1000 corresponds to approximately $25 \%$ of the sample size).
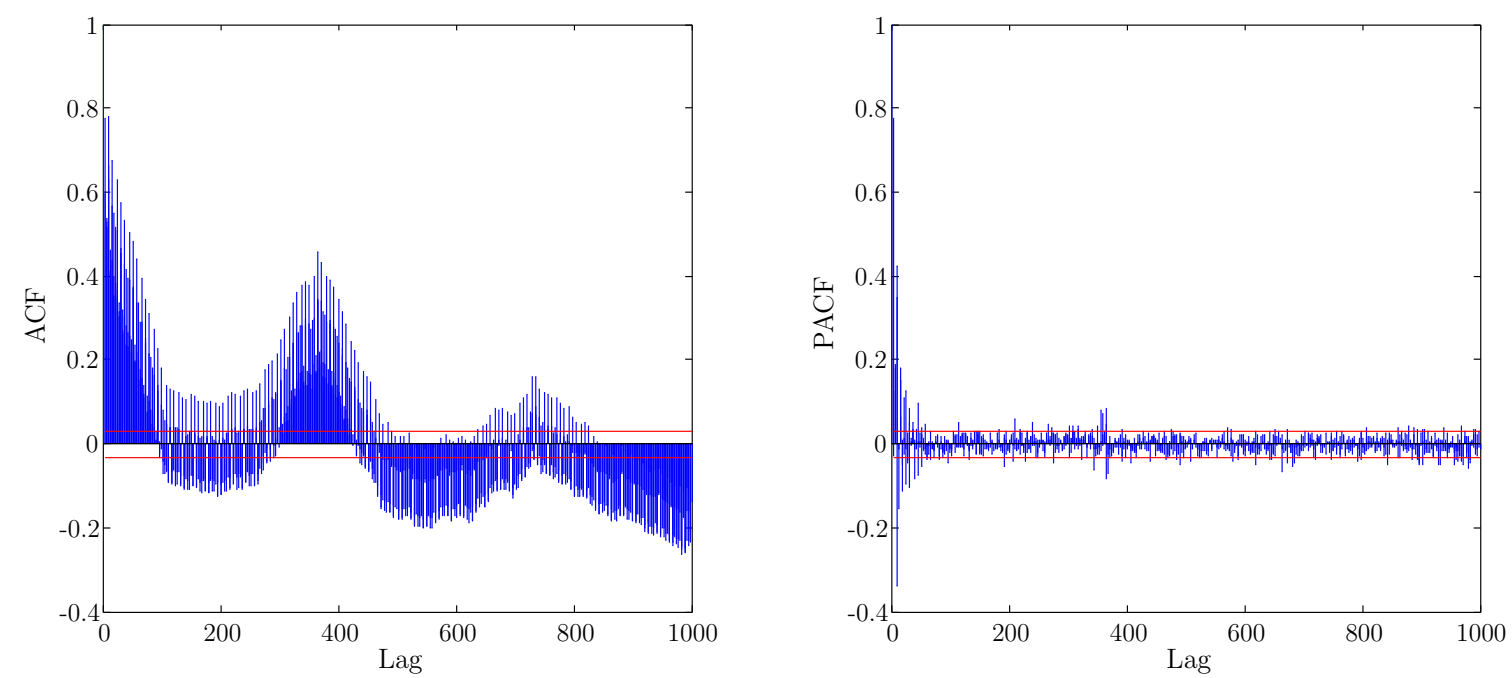

Source: Author's calculations.

Figure 5.1: Correlogram for Daily Electricity Prices

A detailed analysis of the sample autocorrelation function $(\mathrm{ACF})$ reveals the presence of two types of seasonality in electricity prices: weekly seasonality observed through the spikes in the sample ACF at lag orders of $7,14, \ldots$ (integer multiples of 7 ), and annual seasonality observed through the spikes in the sample ACF at lag orders of $364,728, \ldots$ (integer multiples of 364).

The sample partial autocorrelation function (PACF) suggests to additionally consider such lag orders as 9, 16, 28,29,61, 100 to accommodate weekend, monthly, and quarterly patterns. This knowledge is also used in specifying the $A R$ process.

\subsection{Frequency Domain Analysis}

A frequency domain analysis allows to identify frequencies explaining a large portion of seasonal variations in electricity prices. The identified frequencies can then be used in specifying the arguments of periodic sine and cosine functions that are included as additional explanatory variables. A frequency domain is examined using the techniques 
of the spectral (Fourier) analysis. The techniques of the Fourier analysis allow modeling a time series with seasonal components as a sum of periodic $A \cdot \sin (\omega t+\varphi)$ sinusoidal functions, where $A$ denotes the amplitude of a sinusoidal wave, $\omega$ denotes a frequency, and $\varphi$ denotes a phase shift (see, for example, Molinero, 1991; Wang, 2003; Prado and West, 2010). For practical considerations, the periodic sinusoidal function can be rewritten in the following way: $A \cdot \sin (\omega t+\varphi)=A \cdot \sin \varphi \cdot \cos (\omega t)+A \cdot \cos \varphi \cdot \sin (\omega t)$. The rewritten expression suggests using $\cos (\omega t)$ and $\sin (\omega t)$ trigonometric functions as explanatory variables for modeling the seasonal pattern of electricity prices. Assuming that $\omega$ is known (as described later, it will be determined based on the Fourier transform), estimates of the slope parameters can then allow calculating the respective amplitude and phase shift.

The Fourier transform of a real-valued function $p(t)$ on the domain $[0, T]$ is defined as $F(i \omega)=\mathcal{F}\{p(t)\}=\int_{0}^{T} p(t) e^{-i \omega t} d t$, where $i$ is the imaginary unit such that $i^{2}=-1$. Based on this definition, the FFT numerical procedure computes $F\left(i \omega_{k}\right) \approx \sum_{t=0}^{T-1} p_{t} e^{-i \omega_{k} t}$.

It is important to note that the values of the Fourier transform are complex numbers and are therefore not directly comparable. For this reason I use the absolute values of the Fourier transform. A detailed description is presented in Appendix A.

A graph where the frequency domain is plotted against the absolute values of the Fourier transform is known as a periodogram. In Figure 5.2 I present a periodogram plot for daily electricity prices.

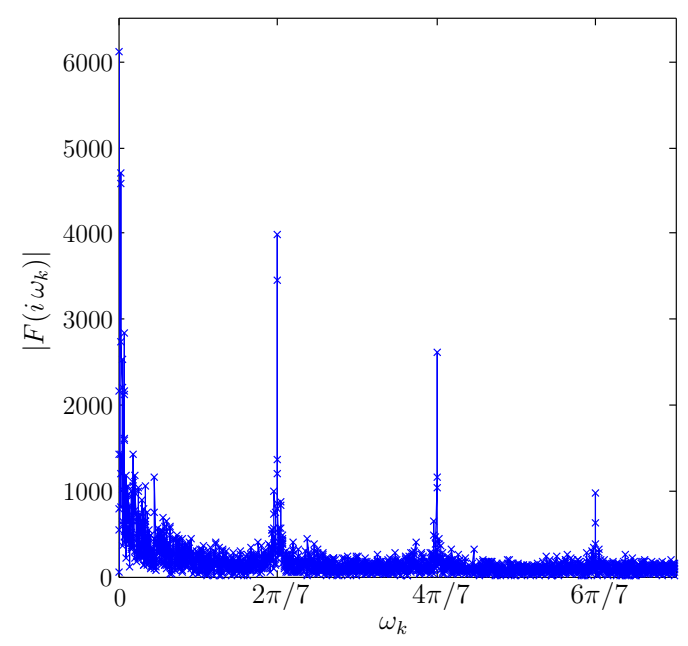

Source: Author's calculations.

Figure 5.2: Periodogram for Daily Electricity Prices

A detailed analysis of the frequency domain, where the absolute values of the Fourier 
transform achieve local maxima, as described in the periodogram in Figure 5.2, allows revealing frequencies that explain the seasonal pattern in the price time series. Hence, the frequencies at which the absolute values of the Fourier transform achieve local maxima can be used in specifying the argument of sine and cosine functions included as additional explanatory variables.

The application of sine and cosine functions in modeling weekly seasonality is preferred to the application of daily dummy variables because the former approach has resulted in a more parsimonious model. An application of smooth periodic functions rather than, for example, daily dummy variables is also in line with the suggestion for future extensions mentioned in Koopman et al. (2007).

\section{$5.4 A R-A R C H$ Model Specification}

For the analysis of price and volatility dynamics I employ the $A R(P)-A R C H(p)$ model, which was developed and applied in Engle (1982) to estimate the means and variances of inflation in the UK.

The $A R(P)-A R C H(p)$ model applied for the estimation of volatility of electricity prices can be represented in the following way:

$$
\begin{aligned}
\text { price }_{t} & =a_{0}+\sum_{i=1}^{P} a_{i} \text { price }_{t-i}+\varepsilon_{t} \\
\varepsilon_{t} & =\nu_{t} \sqrt{\alpha_{0}+\sum_{i=1}^{p} \alpha_{i} \varepsilon_{t-i}^{2}}
\end{aligned}
$$

where similarly to Engle (1982) and Koopman et al. (2007) I consider autoregressive conditional heteroscedastic residuals $\varepsilon_{t} . \nu_{t}$ is a sequence of an independent and identically distributed (i.i.d.) random variable with zero mean and unit variance, which are also known as the standardized residuals. The distributional assumption for $\nu_{t}$ is crucial for the joint estimation of the two equations using the maximum likelihood approach. As described, for example, in Hamilton (1994), usually a normal distribution, generalized normal distribution or $t$-distribution is considered. A normal distribution is a special case of a generalized normal distribution when a shape parameter is equal to two.

As the standardized residuals, $\nu_{t}$, is the i.i.d. sequence with zero mean and unit variance, we can also specify the $A R(P)-A R C H(p)$ model in the following way: 


$$
\begin{aligned}
\text { price }_{t} & =a_{0}+\sum_{i=1}^{P} a_{i} \text { price }_{t-i}+\varepsilon_{t} \\
h_{t} & =\alpha_{0}+\sum_{i=1}^{p} \alpha_{i} \varepsilon_{t-i}^{2}
\end{aligned}
$$

where $h_{t}=E_{t-1}\left[\varepsilon_{t}^{2}\right]$ is the conditional variance or volatility.

The two equations describing the $A R(P)$ and $A R C H(p)$ processes are called the mean and conditional volatility equations, respectively. This specification captures in particular such inherent properties of electricity prices as mean reversion, spikes, and volatility clustering.

The error term $\varepsilon_{t}$ in the $A R(P)$ process is assumed not to contain any serial correlation. The appropriateness of a chosen specification for the $A R(P)$ process is examined using the $\mathrm{ACF}, \mathrm{PACF}$, and $p$-values of the Ljung-Box $Q$-test statistics.

To ensure that the conditional volatility $h_{t}$ is positive, it is usually assumed that $\alpha_{0}>0$ and $\alpha_{i} \geq 0$. The implication of the $A R C H$ term in the conditional volatility equation is reviewed, for example, in Kočenda and Černý (2007). In particular, the $A R C H$ term $\varepsilon_{t-1}^{2}$ is designed to reflect the impact of a shock or news from the previous period that would affect the current conditional volatility. More precisely, a significant and positive $\alpha_{i}$ less than one would measure the extent of a past shock's effect on the volatility, which is not destabilizing. Additionally, it is also possible to distinguish the impact of positive and negative shocks from a previous period, which can asymmetrically affect the volatility. This is investigated by a threshold $A R C H$ process developed in Glosten et al. (1993).

Similarly to Koopman et al. (2007), I extend the mean and volatility equations to include explanatory variables represented in this research by periodic sine and cosine functions with frequencies suggested by the Fourier transform. In order to evaluate the impact of institutional changes and regulatory reforms on the dynamics of electricity prices, I also additionally include regime dummy variables, because I assume that the institutional changes and regulatory reforms could have affected the price development. The validity of the proposed assumption is verifiable by formal hypothesis testing. The regime periods are determined based on the known time of the institutional changes and regulatory reforms that took place in the ESI in Great Britain during 1990-2001. 
The joint estimation of the mean and conditional volatility equations is dependent on the distributional assumption of $\nu_{t}$. Usually a $t$-distribution or generalized normal distribution is considered. The adequacy of the overall $A R(P)-A R C H(p)$ model is verified by testing if the standardized residuals, $\hat{\nu}_{t}=\frac{\hat{\varepsilon}_{t}}{\sqrt{\hat{h}_{t}}}$, is an i.i.d. sequence. For this purpose, I apply the BDS test developed by Brock et al. (1996). Because the conclusion of the BDS test can in general depend on the values of the embedding dimension and proximity parameters, I also additionally analyze the $p$-values of the Ljung-Box $Q$-test statistics to examine whether $\hat{\nu}_{t}$ and $\hat{\nu_{t}^{2}}$ contain any serial correlation. This is done as a robustness check for the judgement on model adequacy.

\section{Results}

Based on the presented methodology, the following dynamic model is estimated:

$$
\begin{aligned}
\text { price }_{t} & =a_{0}+\sum_{i=1}^{P} a_{i} \text { price }_{t-i}+z_{t}^{\prime} \cdot \gamma+\varepsilon_{t} \\
h_{t} & =\alpha_{0}+\sum_{i=1}^{p} \alpha_{i} \varepsilon_{t-i}^{2}+z_{t}^{\prime} \cdot \delta
\end{aligned}
$$

where $z_{t}$ is a vector of additional explanatory variables including periodic sine and cosine functions and regime dummy variables. The estimation results obtained using the Marquardt algorithm are summarized in Table 6.1.

Attempts to model weekly seasonality through the application of daily dummy variables were not as successful as the application of smooth periodic sine and cosine functions, where the frequencies are chosen based on the Fourier transform. In particular, the application of sine and cosine functions has resulted in a more parsimonious model. Weekly seasonality is additionally modeled through a lag structure in both the mean and conditional volatility equations. The mean equation also includes a yearly lag, which is statistically significant.

It is interesting to note that weekly seasonality modeled in the conditional volatility equation is found to be complex to also contain asymmetries with respect to positive and negative shocks (or innovations). As the estimation results indicate, there is evidence at the $5 \%$ significance level that positive shocks from the previous week have a larger effect on the volatility. 
Table 6.1: Estimation Results of the Extended AR-ARCH Model

price $_{t}=a_{0}+\sum_{i=1}^{P} a_{i}$ price $_{t-i}+z_{t}^{\prime} \cdot \gamma+\varepsilon_{t}$
$h_{t}=\alpha_{0}+\sum_{i=1}^{p} \alpha_{i} \varepsilon_{t-i}^{2}+z_{t}^{\prime} \cdot \delta$

\begin{tabular}{|c|c|c|c|c|c|}
\hline \multicolumn{6}{|c|}{ Dependent Variable: pricet $_{t}$} \\
\hline \multicolumn{3}{|c|}{ Mean Equation } & \multicolumn{3}{|c|}{ Conditional Volatility Equation } \\
\hline Variable & Coef. & Std. Err. & Variable & Coef. & Std. Err. \\
\hline$a_{0}$ & $0.836^{* * *}$ & 0.262 & $\alpha_{0}$ & $0.604^{* * *}$ & 0.069 \\
\hline price $_{t-1}$ & $0.600 * * *$ & 0.015 & $\varepsilon_{t-1}^{2}$ & $0.174 * * *$ & 0.027 \\
\hline price $_{t-2}$ & $0.068 * * *$ & 0.016 & $\varepsilon_{t-3}^{t-1}$ & $0.019 *$ & 0.012 \\
\hline price $_{t-3}$ & $0.033 * *$ & 0.014 & $\begin{array}{l}t-3 \\
\varepsilon_{t-4}^{2}\end{array}$ & $0.092 * * *$ & 0.021 \\
\hline price $_{t-4}$ & $0.048 * * *$ & 0.014 & $\varepsilon_{t-5}^{t-4}$ & $0.110^{* * *}$ & 0.020 \\
\hline price $_{t-6}$ & $0.084 * * *$ & 0.013 & $\varepsilon_{t-7}^{2}$ & $0.293 * * *$ & 0.039 \\
\hline price $_{t-7}$ & $0.241 * * *$ & 0.019 & $\varepsilon_{t-7}^{2-r} \cdot I_{t-7}$ & $-0.124 * *$ & 0.054 \\
\hline price $_{t-8}$ & $-0.101 * * *$ & 0.017 & $\varepsilon_{t-9}^{t-r}$ & $0.051 * * *$ & 0.019 \\
\hline price $_{t-9}$ & $-0.107 * * *$ & 0.015 & $\cos (4 \pi t / 7)$ & $-0.383 * * *$ & 0.091 \\
\hline price $_{t-14}$ & $0.096 * * *$ & 0.012 & $\cos (6 \pi t / 7)$ & $0.554 * * *$ & 0.089 \\
\hline price $_{t-16}$ & $-0.065 * * *$ & 0.011 & $\sin (2 \pi t / 7)$ & $0.646 * * *$ & 0.102 \\
\hline price $_{t-21}$ & $0.071 * * *$ & 0.011 & $\sin (4 \pi t / 7)$ & $-0.308 * * *$ & 0.057 \\
\hline price $_{t-25}$ & $-0.038 * * *$ & 0.009 & $\sin (6 \pi t / 7)$ & $-0.548 * * *$ & 0.087 \\
\hline price $_{t-28}$ & $0.070 * * *$ & 0.013 & Regime 2 & 0.118 & 0.083 \\
\hline price $_{t-29}$ & $-0.069 * * *$ & 0.012 & Regime 3 & $1.223 * * *$ & 0.240 \\
\hline price $_{t-42}$ & $0.044 * * *$ & 0.012 & Pre-Regime 4 & $3.455 * * *$ & 1.343 \\
\hline price $_{t-43}$ & $-0.032 * * *$ & 0.011 & Regime 4 & $2.130 * * *$ & 0.356 \\
\hline price $_{t-48}$ & $0.015 *$ & 0.009 & Regime 5 & $1.152 * * *$ & 0.220 \\
\hline price $_{t-61}$ & -0.009 & 0.007 & & & \\
\hline price $_{t-100}$ & $-0.024 * * *$ & 0.006 & Shape Parameter & 1.273 & 0.036 \\
\hline price $_{t-207}$ & $-0.021 * * *$ & 0.007 & & & \\
\hline price $_{t-209}$ & $0.025 * * *$ & 0.007 & & & \\
\hline price $_{t-260}$ & $-0.018^{* * *}$ & 0.006 & & & \\
\hline price $_{t-270}$ & $0.013 * *$ & 0.006 & & & \\
\hline price $_{t-341}$ & $0.026 * * *$ & 0.008 & & & \\
\hline price $_{t-344}$ & $-0.026 * * *$ & 0.007 & & & \\
\hline price $_{t-355}$ & $-0.041 * * *$ & 0.009 & & & \\
\hline price $_{t-357}$ & $0.037 * * *$ & 0.010 & & & \\
\hline price $_{t-364}$ & $0.043 * * *$ & 0.009 & & & \\
\hline $\cos (2 \pi t / 7)$ & $-0.131 * * *$ & 0.042 & & & \\
\hline $\cos (4 \pi t / 7)$ & $-0.252 * * *$ & 0.042 & & & \\
\hline $\cos (6 \pi t / 7)$ & $0.118 * * *$ & 0.033 & & & \\
\hline $\sin (4 \pi t / 7)$ & $-0.124 * * *$ & 0.036 & & & \\
\hline $\sin (6 \pi t / 7)$ & $-0.290 * * *$ & 0.036 & & & \\
\hline Regime 2 & 0.062 & 0.076 & & & \\
\hline Regime 3 & $-0.403 * * *$ & 0.081 & & & \\
\hline Pre-Regime 4 & -0.261 & 0.280 & & & \\
\hline Regime 4 & -0.123 & 0.075 & & & \\
\hline Regime 5 & $-0.328 * * *$ & 0.079 & & & \\
\hline Obs. & 3631 & & & & \\
\hline Adj. $R^{2}$ & 0.804 & & & & \\
\hline $\mathrm{AIC}$ & 4.031 & & & & \\
\hline
\end{tabular}

Source: Author's calculations.

Notes: $I_{t-7}$ is an indicator function equal to 1 if $\varepsilon_{t-7}<0$ and 0 otherwise. The inclusion of a $G A R C H$ term has not improved the results. The functions $\sin (2 \pi t / 7)$ and $\cos (2 \pi t / 7)$ are excluded from the mean and volatility equations respectively, because the corresponding estimated slope coefficients are statistically insignificant. ${ }^{*}, * *$, and ${ }^{* * *}$ stand for the $10 \%, 5 \%$, and $1 \%$ significance levels, respectively. 
The sum of the coefficients of the lagged variables is less than unity (0.965 in the mean equation and 0.738 in the conditional volatility equation), which suggests that the effects of past prices and shocks are not destabilizing. Moreover, the nonnegativity requirement of the coefficients of the $A R C H$ terms is also satisfied. The latter is necessary to ensure that the conditional volatility is positive.

The assumption that the standardized residuals $\nu_{t}$ have a $t$-distribution is rejected at the $1 \%$ significance level. Therefore, a generalized normal distribution (also known as a generalized error distribution) is considered. The estimation results presented in Table 6.1 include an estimate of the shape parameter, which suggests that tails are leptokurtic, i.e., heavier than those of a standard normal distribution. This is an often-cited result in the literature dealing with modeling and forecasting electricity price dynamics (see, for example, Koopman et al., 2007). The distribution of $\hat{\nu}_{t}$ presented in Figure 6.1, in comparison with the normal distribution, suggests that the assumption of the generalized normal distribution for $\nu_{t}$ works reasonably well.

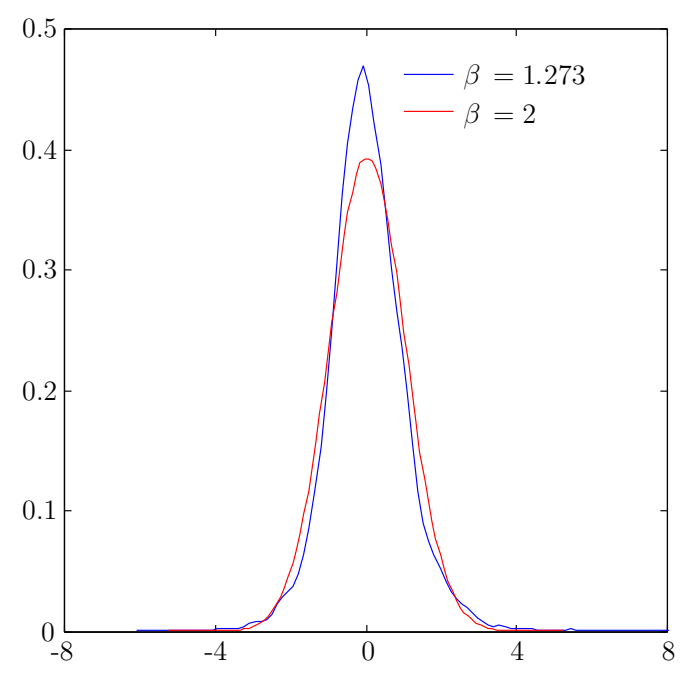

Source: Author's calculations.

Figure 6.1: Density of $\hat{\nu}_{t}$ and the Normal Distribution

In order to check the adequacy of the estimated extended $A R-A R C H$ model, I also apply the BDS test developed by Brock et al. (1996) to test if the standardized residuals $\hat{\nu}_{t}$ are i.i.d. For the embedding dimension $m$ equal to 2 and 3 and a default option of 
the proximity parameter $\varepsilon$, the null hypothesis that the standardized residuals are i.i.d. is not rejected. This test, therefore, confirms the adequacy of the estimated $A R-A R C H$ model. The test results are summarized in Table 6.2.

Table 6.2: BDS Test for Standardized Residuals $\hat{\nu}_{t}$

\begin{tabular}{cccc}
\hline Dimension & BDS Stat. & Std. Err. & $p$-value \\
\hline 2 & -0.001 & 0.001 & 0.500 \\
3 & 0.002 & 0.002 & 0.260 \\
\hline
\end{tabular}

Source: Author's calculations.

Because the conclusion of the BDS test can in general be sensitive to the choice of $m$ and $\varepsilon$ parameters, as a robustness check for model adequacy, I additionally examine if the standardized residuals $\hat{\nu}_{t}$ and standardized residuals squared $\hat{\nu_{t}^{2}}$ contain any serial correlation. For this purpose I examine the $p$-values of the Ljung-Box $Q$-test statistics. The test results are summarized in Figure 6.2.
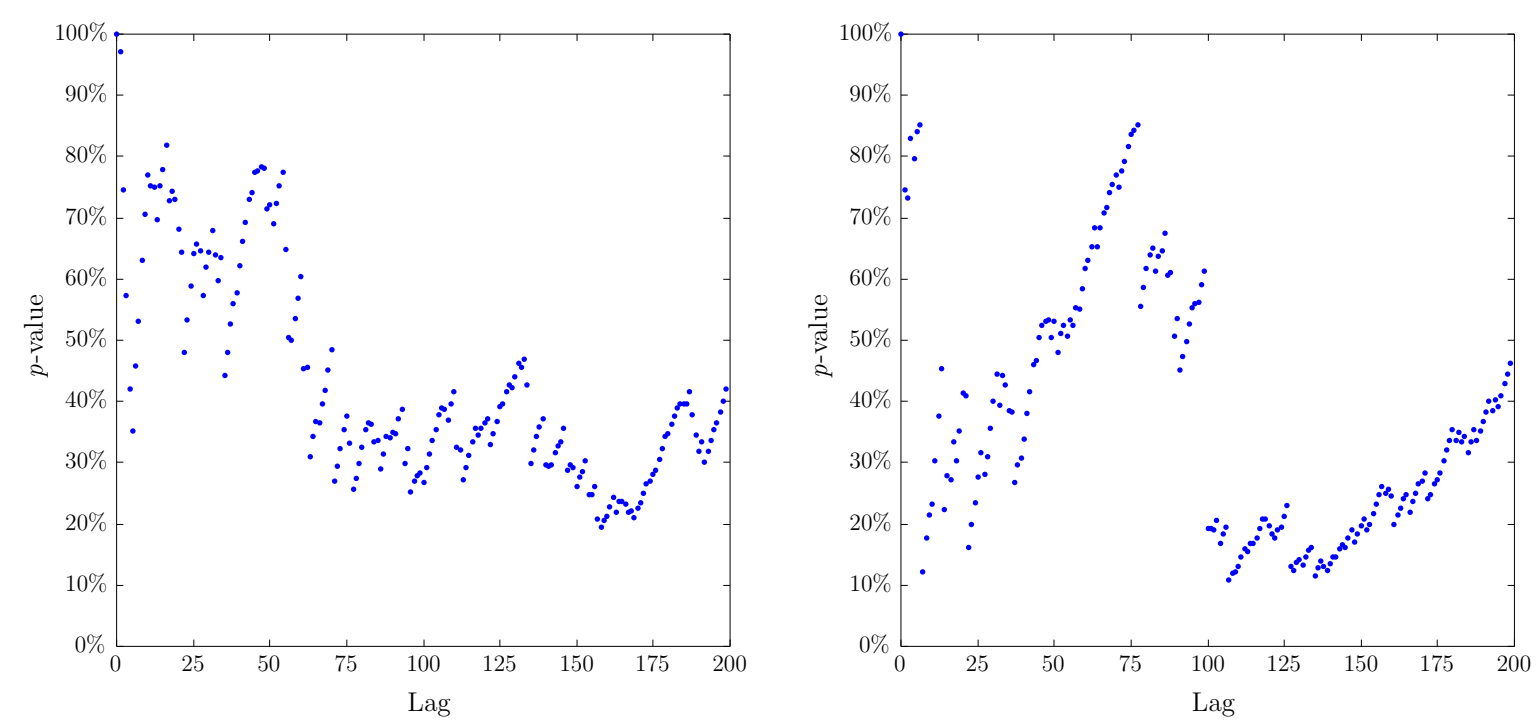

Source: Author's calculations.

Figure 6.2: Ljung-Box Q-Test for Standardized Residuals $\hat{\nu}_{t}$ and $\hat{\nu_{t}^{2}}$

The test results presented in Figure 6.2 provide evidence at the $5 \%$ significance level that the standardized residuals $\left(\hat{\nu}_{t}\right)$ and standardized residuals squared $\left(\hat{\nu_{t}^{2}}\right)$ do not have 
any serial correlation. These findings suggest that the residuals do not contain any further information and therefore justify the appropriateness of the joint estimation of the mean and conditional volatility equations. Overall, the estimated extended $A R-A R C H$ model explains about $80 \%$ of variations in electricity prices.

Using the estimation results presented in Table 6.1, I summarize in relative terms the effects of the institutional changes and regulatory reforms on price and volatility dynamics for the case of the England and Wales electricity market during 1990-2001. This is presented in Figure 6.3.

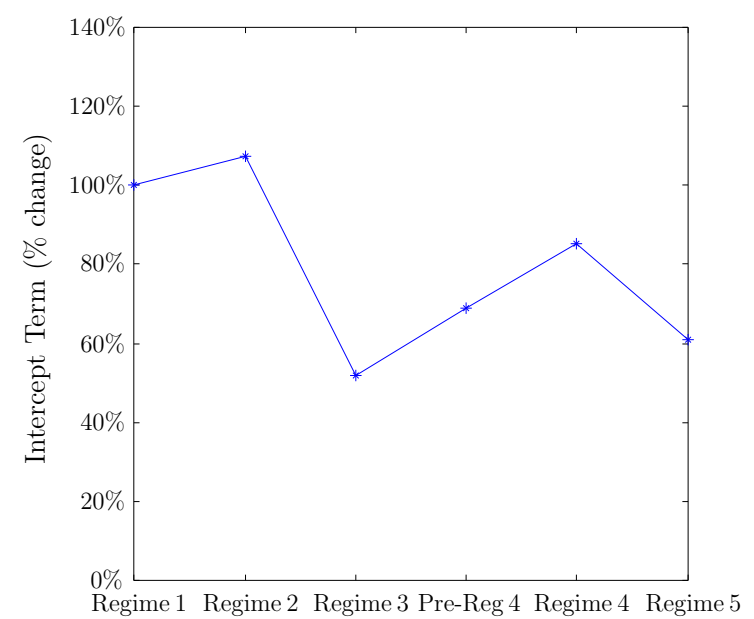

(a) Mean Equation

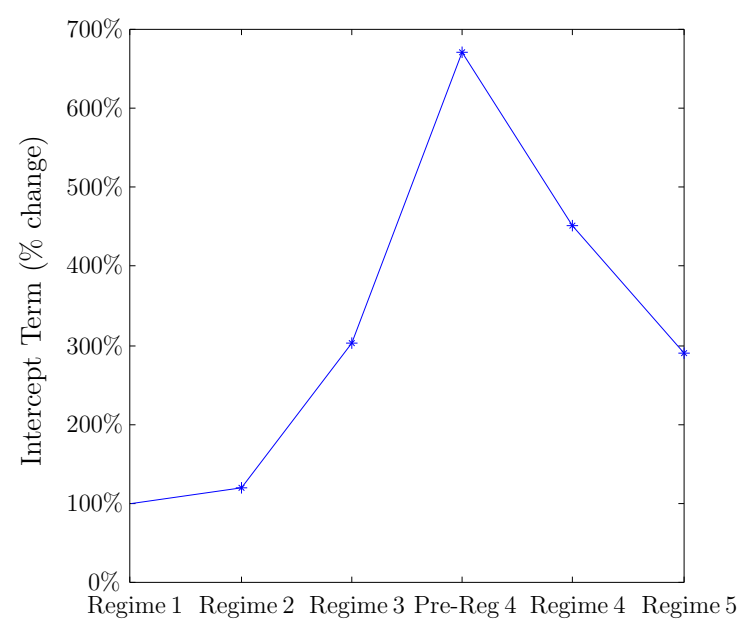

(b) Conditional Volatility Equation

Source: Author's calculations.

Figure 6.3: Impact of the Institutional Changes and Regulatory Reforms on Price and Volatility Dynamics

When the initial coal contracts expired, the electricity prices on average became slightly higher and more volatile. These changes, however, are neither statistically nor economically significant compared to the reference period, i.e., regime 1.

During the price-cap regulation period (i.e., regime 3) we observe a decrease in the price level, which however happens at the cost of higher volatility. These changes are both statistically and economically significant. This result is also partly consistent with the finding in Wolfram (1999) that the price-cap regulation led the industry supply curve to rotate counterclockwise, because in order to satisfy the price cap producers reduced 
prices when demand was low and increased them when demand was high.

Using nonparametric techniques for weekly electricity prices during December 10, 1990 - March 11, 1996, Robinson and Baniak (2002) also find that after the expiry of the coal contracts in 1993 and during price-cap regulation, price volatility increased, for which the authors provide an alternative explanation. In particular, they state that the incumbent electricity producers could have been deliberately increasing price volatility in order to enjoy higher risk premia in the contract market. However, because data on contracts are confidential, it is hard to empirically verify this statement.

During the period after price-cap regulation and before the first series of divestments took place, the price volatility increased dramatically, whereas an increase in the price level is only economically significant. This can possibly be characterized as a transitional feature of the pre-regime 4 period. During regime 4 , when the first series of divestments took place, the volatility decreased, whereas the price level increased further compared to the pre-regime 4 period. This finding indicates that during regime 4 the trade-off has reversed: lower volatility is achieved at the cost of a higher price level. The increased price level and decreased price volatility during this period could be related to tacit collusion discussed, for example, in Sweeting (2007).

The estimation results indicate that the second series of divestments was more successful. In particular, the price level and volatility are both reduced. This finding supports the implementation of the second series of divestments.

From the perspective of the presented time series modeling approach, it follows that price-cap regulation and divestment series led in the end to similar price levels and volatility. However, usually divestment series could be superior to price regulation because they allow for the creation of a less concentrated market structure, where it is easier to promote competitive bidding among electricity producers. 


\section{Conclusions}

This study aims to analyze the impact of introduced institutional changes and regulatory reforms on price and volatility dynamics. For this purpose, time and frequency domain analyses are used to appropriately model seasonality in electricity prices. The methodology based on the application of sine and cosine functions whose frequencies are determined from the Fourier transform rather than based on the application of the daily dummy variables is found to be more appropriate for modeling weekly seasonality in electricity prices. As a result, a more parsimonious $A R-A R C H$ model has been considered. Moreover, the estimation results of the extended $A R-A R C H$ model indicate that innovations from the previous week have asymmetric effects on volatility. In particular, I find that positive innovations from the previous week have a larger effect on volatility.

This research also documents new results in quantifying the impact of institutional changes and regulatory reforms on price and volatility dynamics for the case of the England and Wales wholesale electricity market during 1990-2001. Firstly, I find the presence of a trade-off in introducing price-cap regulation, which is both statistically and economically significant. In particular, estimation results indicate that a lower price level was achieved at the expense of higher volatility. Secondly, the implementation of the first series of divestments was successful at lowering price volatility, which however happened at the cost of a higher price level. This is explained as the possible presence of tacit collusion. Thirdly, only during the last regime period, when the second series of divestments was implemented, was it possible to simultaneously reduce prices and volatility. The findings and conclusions of this study of the impact of the institutional changes and regulatory reforms on the dynamics of electricity prices could be of interest to, for example, Argentina, Australia, Chile, Italy, Spain, and some US states, which have organized the operation of their modern electricity markets similar to the original model of the England and Wales wholesale electricity market. 


\section{References}

Bosco, B. P., L. P. Parisio, and M. M. Pelagatti, "Deregulated Wholesale Electricity Prices in Italy: An Empirical Analysis," International Advances in Economic Research, 2007, 13 (4), 415-432.

Brock, W. A., W. D. Dechert, J. A. Scheinkman, and B. LeBaron, "A Test for Independence Based on the Correlation Dimension," Econometric Reviews, 1996, 15 (3), 197-235.

Conejo, A. J., J. Contreras, R. Espínola, and M. A. Plazas, "Forecasting Electricity Prices for a Day-Ahead Pool-Based Electric Energy Market," International Journal of Forecasting, 2005, 21 (3), 435-462.

Crawford, G. S., J. Crespo, and H. Tauchen, "Bidding Asymmetries in MultiUnit Auctions: Implications of Bid Function Equilibria in the British Spot Market for Electricity," International Journal of Industrial Organization, 2007, 25 (6), 1233-1268.

Crespo, J. C., J. Hlouskova, S. Kossmeier, and M. Obersteiner, "Forecasting Electricity Spot-Prices Using Linear Univariate Time-Series Models," Applied Energy, 2004, 77 (1), 87-106.

Department of Trade and Industry, Digest of United Kingdom Energy Statistics, London, UK: The Stationery Office, 1997-2002.

Engle, R. F., "Autoregressive Conditional Heteroscedasticity with Estimates of the Variance of United Kingdom Inflation," Econometrica, 1982, 50 (4), 987-1007.

Franses, P. H. and R. Paap, Periodic Time Series Models Advanced Texts in Econometrics, New York, USA: Oxford University Press, 2004.

Garcia, R. C., J. Contreras, M. van Akkeren, and J. B. C. Garcia, "A GARCH Forecasting Model to Predict Day-Ahead Electricity Prices," IEEE Transactions on Power Systems, 2005, 20 (2), 867-874.

Gençay, R., F. Selçuk, and B. Whitcher, An Introduction to Wavelets and Other Filtering Methods in Finance and Economics, San Diego, USA: Academic Press, 2002.

Glosten, L. R., R. Jagannathan, and D. E. Runkle, "On the Relation Between the Expected Value and the Volatility of the Nominal Excess Returns on Stocks," The Journal of Finance, 1993, 48 (5), 1779-1801.

Green, R. J. and D. M. Newbery, "Competition in the British Electricity Spot Market," Journal of Political Economy, 1992, 100 (5), 929-953.

Guthrie, G. and S. Videbeck, "Electricity Spot Price Dynamics: Beyond Financial Models," Energy Policy, 2007, 35 (11), 5614-5621. 
Hamilton, J. D., Time Series Analysis, Princeton, USA: Princeton University Press, 1994.

Huisman, R., C. Huurman, and R. Mahieu, "Hourly Electricity Prices in DayAhead Markets," Energy Economics, 2007, 29 (2), 240-248.

Joskow, P. L., "Foreword: US vs. EU Electricity Reforms Achievement," in J.-M. Glachant and F. Lévêque, eds., Electricity Reform in Europe, Cheltenham, UK: Edward Elgar Publishing Limited, 2009.

Koopman, S. J., M. Ooms, and M. A. Carnero, "Periodic Seasonal Reg-ARFIMAGARCH Models for Daily Electricity Spot Prices," Journal of the American Statistical Association, 2007, 102 (477), 16-27.

Kočenda, E. and A. Černý, Elements of Time Series Econometrics: An Applied Approach, Prague, Czech Republic: Karolinum Press, 2007.

Molinero, C. M., "The Autocorrelation Function of a Time Series with a Deterministic Component," IMA Journal of Mathematics Applied in Business and Industry, 1991, 3 (1), 25-30.

National Grid Company, Seven Year Statement, London, UK: National Grid Company, 1994-2001.

Newbery, D. M., "The UK Experience: Privatization with Market Power," University of Cambridge, Mimeo, 1999, pp. 1-23.

Prado, R. and M. West, Time Series Modeling, Computation, and Inference Texts in Statistical Science, Boca Raton, USA: CRC Press, 2010.

Robinson, T. and A. Baniak, "The Volatility of Prices in the English and Welsh Electricity Pool," Applied Economics, 2002, 34 (12), 1487-1495.

Sweeting, A., "Market Power in the England and Wales Wholesale Electricity Market 1995-2000," The Economic Journal, 2007, 117 (520), 654-685.

Tashpulatov, S. N., "Analysis of Electricity Industry Liberalization in Great Britain: How Did the Bidding Behavior of Electricity Producers Change?," CERGE-EI Working Paper Series No. 415, 2010, pp. 1-55.

Von der Fehr, N.-H. M. and D. Harbord, "Spot Market Competition in the UK Electricity Industry," The Economic Journal, 1993, 103 (418), 531-546.

Wang, P., Financial Econometrics: Methods and Models Routledge Advanced Texts in Economics and Finance, London, UK: Routledge, 2003. 
Wolfram, C. D., "Strategic Bidding in a Multiunit Auction: An Empirical Analysis of Bids to Supply Electricity in England and Wales," The RAND Journal of Economics, 1998, 29 (4), 703-725.

_ , "Measuring Duopoly Power in the British Electricity Spot Market," The American Economic Review, 1999, 89 (4), 805-826. 


\section{Appendices}

\section{A Fourier Transform}

The Fourier transform of a real-valued function $p(t)$ on the domain $[0, T]$ is defined as

$$
F(i \omega)=\mathcal{F}\{p(t)\}=\int_{0}^{T} p(t) \cdot e^{-i \omega t} d t
$$

where $i$ is the imaginary unit such that $i^{2}=-1$.

Using the above definition, we can write the following approximation for the Fourier transform:

$$
\begin{aligned}
F\left(i \omega_{k}\right) \approx \sum_{t=0}^{T-1} p_{t} \cdot e^{-i \omega_{k} t} & =\sum_{t=0}^{T-1} p_{t} \cdot\left(\cos \omega_{k} t-i \sin \omega_{k} t\right)= \\
& =\sum_{t=0}^{T-1} p_{t} \cdot \cos \omega_{k} t-i \sum_{t=0}^{T-1} p_{t} \cdot \sin \omega_{k} t= \\
& =\left(p_{t}, \cos \omega_{k} t\right)-i\left(p_{t}, \sin \omega_{k} t\right)
\end{aligned}
$$

where $\omega_{k}=\frac{k}{N-1} \cdot 2 \pi, \quad k=0,1,2, \ldots, N-1$, and $N$ determines the grid.

Because the values of the Fourier transform are complex numbers, they are not directly comparable. For this reason we use the absolute values of the Fourier transform.

The optimization problem can therefore be described in the following way:

$$
\left|F\left(i \omega_{k}\right)\right| \approx\left|\left(p_{t}, \cos \omega_{k} t\right)-i\left(p_{t}, \sin \omega_{k} t\right)\right| \longrightarrow \max _{\omega_{k}}
$$

where $\omega_{k}=\frac{k}{N-1} \cdot 2 \pi, \quad k=0,1,2, \ldots, N-1$, and $N$ determines the grid.

The expressions in parentheses represent scalar products. In statistical terms, they measure covariation between the price time series and cosine/sine functions for different values of $\omega_{k}$. In this optimization problem, our task is to find such values of $\omega_{k}$ that would explain a large portion of variation in the electricity prices. The results have been computed using the FFT procedure implemented in MatLab. 


\section{B Abbreviations}

$\mathrm{ACF}$

$\mathrm{ADF}$

AIC

APX

AR

$\mathrm{ARCH}$

ARIMA

ARMA

BDS

EEX

ESI

FFT

GARCH

NEM

NGC

OFFER

PACF

PPX

SFE

SMP

SUR
Autorcorrelation Function

Augmented Dickey-Fuller

Akaike Information Criterion

Amsterdam Power Exchange

Autoregressive

Autoregressive Conditional Heteroscedasticity

Autoregressive Integrated Moving Average

Autoregressive Moving Average

Brock Dechert Scheinkman

European Energy Exchange (Germany)

Electricity Supply Industry

Fast Fourier Transform

Generalized Autoregressive Conditional Heteroscedasticity

New Zealand Electricity Market

National Grid Company

Office of Electricity Regulation

Partial Autorcorrelation Function

Paris Power Exchange

Supply Function Equilibrium

System Marginal Price

Seemingly Unrelated Regressions 
Working Paper Series

ISSN 1211-3298

Registration No. (Ministry of Culture): E 19443

(c) Sherzod N. Tashpulatov, 2011

All rights reserved. No part of this publication may be reproduced, stored in a retrieval system or transmitted in any form or by any means, electronic, mechanical or photocopying, recording, or otherwise without the prior permission of the publisher.

Published by

Charles University in Prague, Center for Economic Research and Graduate Education (CERGE) and

Economics Institute ASCR, v. v. i. (EI)

CERGE-El, Politických vězňů 7, 11121 Prague 1, tel.: +420 224005 153, Czech Republic.

Printed by CERGE-EI, Prague

Subscription: CERGE-EI homepage: http://www.cerge-ei.cz

Phone: + 420224005153

Email: office@cerge-ei.cz

Web: http://www.cerge-ei.cz

Editor: Michal Kejak

Editorial board: Jan Kmenta, Randall Filer, Petr Zemčík

The paper is available online at http://www.cerge-ei.cz/publications/working_papers/.

ISBN 978-80-7343-240-9 (Univerzita Karlova. Centrum pro ekonomický výzkum a doktorské studium)

ISBN 978-80-7344-231-6 (Národohospodářský ústav AV ČR, v. v. i.) 
CERGE-EI

P.O.BOX 882

Politických vězňů 7

11121 Praha 1

Czech Republic http://www.cerge-ei.cz 